This is the author's final, peer-reviewed manuscript as accepted for publication. The publisher-formatted version may be available through the publisher's web site or your institution's library.

\title{
Academic freedom and the professional responsibilities of applied ethicists: a comment on Minerva
}

Angus Dawson and Jonathan Herington

\section{How to cite this manuscript}

If you make reference to this version of the manuscript, use the following information:

Dawson, A. \& Herington, J. (2014). Academic freedom and the professional responsibilities of applied ethicists: A comment on Minerva. Retrieved from http://krex.ksu.edu

\section{Published Version Information}

Citation: Dawson, A. \& Herington, J. (2014). Academic freedom and the professional responsibilities of applied ethicists: A comment on Minerva. Bioethics, 28(4), 174-177.

Copyright: @ 2014 John Wiley \& Sons Ltd

Digital Object Identifier (DOI): doi:10.1111/bioe.12095

Publisher's Link: http://onlinelibrary.wiley.com/doi/10.1111/bioe.12095/full

This item was retrieved from the K-State Research Exchange (K-REx), the institutional repository of Kansas State University. K-REx is available at http://krex.ksu.edu 


\title{
Academic Freedom and the Professional Responsibilities of Applied Ethicists: A comment on Minerva ${ }^{1}$
}

\author{
Angus Dawson and Jonathan Herington
}

Academic freedom is an important good, but it comes with several responsibilities. In this commentary we seek to do two things. First, we argue against Francesca Minerva's view of academic freedom as presented in her paper 'New threats to academic freedom' on a number of grounds. ${ }^{2}$ Second, we identify some of the responsibilities of applied ethicists, and illustrate how they recommend against allowing the anonymous publication of research.

We wish to begin by stating that we believe that what happened to Dr Minerva and her co-author Dr Giubilini on the publication of their joint paper 'After-birth abortion: why should the baby live?'3 was completely unacceptable. Many of the responses to their paper were sensational and sometimes, but not always, misrepresented their arguments and conclusion. Abhorrence at the idea of neo-natal killing was accompanied by wholesale personal denunciations and abuse of the authors, including vile misogyny and threats of violence. No one should be subjected to such threats (indeed, they are, rightly, criminal acts in many jurisdictions), and it is understandable that both authors were seriously affected by the fallout from publication. However, it seems either disingenuous or naïve to claim that a paper titled 'After-birth abortion' would not attract the vociferous attention of the hateful. All of those involved (authors, reviewers and editors) should have foreseen that the deliberate selection of this provocative phrase in the title and support for the view that 'after-birth abortion (killing a newborn) should be permissible in all the cases where abortion is', were bound to attract outrage from some quarters.

So, despite our sympathy for what happened, we do not agree with Minerva's views on what defending academic freedom in the $21^{\text {st }}$ century requires. Rather, we take a different lesson from the case, which is that the right of academics to say and publish whatever they want is not absolute and must be balanced against countervailing professional responsibilities. These responsibilities weigh particularly heavily against anonymous publication of controversial research. Indeed, we take it that the very experience of Giublini and Minerva can be taken as a good example of exactly the problem that anonymity brings. In addition, it points to the wider perils of a public discourse which eschews the calm and careful discussion of ideas.

\section{The True Nature of Academic Freedom and its Implications}

We offer three reasons to reject the view of academic freedom that Minerva wants to defend in her paper. First, it seems to involve a commitment to an absolute conception of a right to academic freedom and is, ultimately, we think, deeply implausible. Second, there are no good reasons to see academics as having any special epistemic powers that allow them, rather than everyday citizens, greater access to truth. Third, although it is not used in Minerva's paper, a possible argument in support of her position would be to invoke a distinction

\footnotetext{
${ }^{1}$ published in Bioethics (2014) Volume 28, Issue 4: pp. 174-177 (DOI: 10.1111/bioe.12095)

${ }^{2}$ Minerva, F. (2014) 'New threats to academic freedom', Bioethics, 28 (4): 157-162

${ }^{3}$ Giublini, A. \& Minerva, F. (2012) 'After-birth abortion: why should the baby live?', Journal of Medical Ethics.
} 
between harm and offense, and argue that free speech by academics (including the 'Afterbirth abortion' paper) was justified because it was (at worst) merely offensive. However, we argue that this view is problematic and will not do the work that Minerva wishes it to do.

First, in her piece, Minerva never states clearly the exact moral status of her claim about academic freedom. However, the only way to make sense of her argument is to assume that she means this to be an absolute claim: that is, it takes precedence as a right (or other moral claim) over all other morally relevant considerations. For example, Minerva holds a right to academic freedom to be sufficient justification for the publication of peerreviewed material, no matter what its content or perceived social benefit (p9). She holds that the reaction to the 'After-birth abortion' paper clearly violated this right: not merely those reactions that were threatening, but also the large swathe of offensive replies to the argument (e.g. 'if it is okay to kill babies, it must be okay to kill academics') or offensive character assessments (e.g. 'the authors are no different to Adolf Hitler'). Whilst Minerva makes no explicit argument for the right to academic freedom, the authors she appeals to support her claim to the right to publish freely by reference to the social role which academics play: as subject experts who pursue questions of importance, absent fears, prejudices and biases' (p10). Certainly this role provides social benefits - by critiquing widely held views, examining verities, and (in the parlance of research administrators) producing knowledge. If we think these are valuable ends, then we have good reason to reject institutional censure of academics for their published views, to refrain from suppressing research on controversial topics, and to protect academics from threats of violence. However, we can reject the plausibility of an absolute status for academic freedom for the following reasons. It is important to note that academic freedom is merely instrumental to these desired ends, so we must reject Minerva's characterisation of it as a kind of absolute consideration. In addition, harm considerations can, rightly, take priority over a right to academic freedom: we ought not to, for instance, allow academics to publish libellous claims about private individuals or tracts which incite hatred and violence.

Second, notwithstanding the important social role of academics as outlined above, we dispute strongly Minerva's view that academic speech is to be accorded special status. She proposes that academics are to be protected from 'fears, prejudices and biases, whether the academic's own or those of broader society, (which) can hamper her pursuit of truth' (p10). The picture presented is one of the heroic academic discovering truth and then sharing it, when they choose, with the masses. This is an offensively elitist view about how truth is pursued and obtained. Contra Minerva, we contend, with Mill, that truth emerges from the testing of evidence and arguments via disputation within the public realm. ${ }^{4}$ Academics have no special epistemic powers, and so no direct access to truth. They may have the luxury of time and, arguably, special relevant skills and experience in analysis and argumentation that allow them an important role in exploring relevant issues. However, this does not accord their judgments any greater authority than anyone else's, nor does it give them a privileged right to speak over others. Truth is, we believe, ultimately, more likely to be obtained in the town square rather than the ivory tower. In our view, academics can play an important role in contributing to decision-making about policy, but ultimately policy-making is and ought to be the product of a public and democratic process.

${ }^{4}$ J.S. Mill. [1859] On Liberty (and other essays). Oxford: Oxford University Press; 1991 
Third, although Minerva offers no obvious argument for her view about the status of academic freedom, if we move away from her absolutist view, we may be able to defend some aspects of her position by invoking a traditional liberal distinction between speech which may harm and that which (merely) offends. This view argues that we can distinguish cases where an academic directly incites a violent assault (where harm is caused) and cases where someone views their religious or political views as being insulted in reading the work of an academic (that they find offensive). The idea is that the freedom of one individual to say or publish what they wish should not be restricted in a free society by worries about what others might find offensive. How might this distinction apply in this case? Perhaps, it may be argued, the argument and language used in Giubilini and Minerva's paper was (merely) offensive, whereas some of the anonymous responses to it might reasonably be taken to be inciting violence. On this view, the former is justified, the latter not. ${ }^{5}$ However, even if someone wants to defend a harm/offense distinction, it is more difficult than it might appear. In his extensive discussion of the matter Joel Feinberg raises many complications in both drawing the distinction and adopting it as the basis of policy. ${ }^{6}$ For example, we have various interests in the things that we might find the subject of offense, so how do we distinguish offenses from harms? Certain offenses may, legitimately, according to Feinberg, be subject to legal intervention, but if we judge what counts as 'offensive' subjectively, then whatever might offend anyone may then be subject to legal restraint. How do we judge 'offense' objectively? In other words, the harm/offense distinction is one possible means of defending some version of Minerva's position, but it requires sophisticated argument to do so - argument that is currently missing from the paper.

Minerva's proposal for defending the absolute right to academic freedom is to allow academics to publish anonymously, simultaneously freeing them from association with a controversial idea and the consequences of its publication. Even if none of the points raised here have any weight against her view of academic freedom as such, we do not believe anonymous publication is the answer, as we set out below.

\section{Academia, Applied Ethics and Professional Responsibilities}

In the course of determining whether research should be published anonymously, we ought to consider whether academics have certain professional responsibilities in addition to their freedoms. That applied ethicists have professional role responsibilities similar to medical professionals or engineers is, we think, widely accepted if not often acknowledged. ${ }^{7}$ Contra Minerva's view, applied ethics is not a mostly scholastic field of inquiry: its purpose (in so far as it is distinct from normative ethics or meta-ethics) is to inform deliberations on the morality of conduct in the actual world, not just in hypothetical circumstances. This role requires us both to be conscientious philosophers and to be willing to engage with pressing policy issues, including exploring moral issues and reasoning with a wider public audience.

\footnotetext{
${ }^{5}$ Note that the fact that Giublini and Minerva's paper was 'academic free speech' plays no role in this point. This idea appeals to a more general argument about free speech per se.

${ }^{6}$ For a summary, see: Feinberg, J. (1973) Social Philosophy. Eaglewood Cliffs, NJ: Prentice-Hall and for a fuller account see: Feinberg, J. (1987-1990) The Moral Limits of the Criminal Law (Four Volumes). Oxford: Oxford University Press.

7 See, for example, some of the discussions in: Eckenwiler, LA \& Cohn, FG. (eds.) The Ethics of Bioethics: Mapping the Moral Landscape. Baltimore: Johns Hopkins University Press.
} 
In particular, we believe that our social role provides two compelling reasons against allowing the anonymous publication of peer-reviewed work.

First, applied ethicists ought to be cautious about definitively claiming that some act is permissible, rather than simply describing reasons in favour of that conclusion. The danger is that the wider public, for better or worse, may treat applied ethicists as authorities on the bounds of permissible conduct and the scope of our obligations to one another. This trust is understandable since the public typically lack the training and background to invigilate the quality of such reasoning and so may take the conclusions of published, peerreviewed work as sound and provisionally correct (just as they must with the empirical sciences). When an article makes the claim that 'after-birth abortion (killing a newborn) should be permissible in all the cases where abortion is,' ${ }^{8}$ the community at large, understandably, given the social role of academics within our society as described above, are likely to take this to be a well-informed policy recommendation. Whilst Minerva asserts that peer review ought to be enough to ensure quality and legitimate an act of free academic speech, we believe that attaching one's name to an argument is a much stronger incentive to produce quality work than peer review. The numerous problems with the peer-review process have been documented inside and outside philosophy for some time - but most pressing for our purposes here is that it often fails to detect fraudulent science and scholarship. Further complicating the job of peer-reviewers is the increasing specialisation of debates alongside the much greater technical complexity of work in bioethics and applied philosophy. For us, the greatest incentive to consider a conclusion from all angles is not peer review, but the knowledge that our view - not just some view - will be scrutinized both by our peers and the wider community.

Second, being publicly committed to our conclusions guards against the unnecessarily provocative use of language which may undermine effective communication with the public. Language has power, and a poorly chosen phrase can swiftly scuttle the reception of an argument. There is no denying, for instance, that the poor reception of the after-birth abortion' paper was due in part to its provocative (and not very perspicacious) title: one could have expressed the same idea with terms less likely to trigger disgust, such as 'neonatal euthanasia.' Whether or not anonymity breeds carelessness with language is an empirical question, but one with evidence in its favour - even in this case. It's hard to imagine, for instance, that the authors of blogs, comments and tweets attacking the 'Afterbirth abortion' paper would have been as offensive or threatening if they had not been able to remain anonymous. Anonymity removes a powerful incentive to be careful with one's language - the approbation of one's peers - and we have no reason to believe that this would be different in an academic context. Choosing one's language carefully, so as to avoid gratuitous offense, is not to be coerced into conformity, but to take one's place as a responsible and active citizen within a vibrant, disputatious social environment.

These reasons, whilst not a justification for limiting the kinds of conclusions which academics may express, offer reasons to be publicly committed to our conclusions and to be careful in the way we express them: both within, and outside of, professional fora.

\footnotetext{
${ }^{8}$ Giublini \& Minerva, op. cit. note 2.
} 